\title{
Chondrodysplasia with joint dislocations, gPAPP type
}

INSERM

\section{Source}

INSERM. (1999). Orphanet: an online rare disease and orphan drug data base. Chondrodysplasia with joint dislocations, gPAPP type. ORPHA:280586

Chondrodysplasia with joint dislocations, gPAPP type is a rare, genetic, primary bone dysplasia characterized by prenatal onset of disproportionate short stature, shortening of the limbs, cong enital joint dislocations, microg nathia, posterior cleft palate, brachydactyly, short metacarpals and irregular size of the metacarpal epiphyses, supernumerary carpal ossification centers and dysmorphic facial features. In addition, hearing impairment and mild psychomotor delay have also been reported. 